\title{
Isolation and identification of caffeine-degrading bacteria from soil, coffee pulp waste and excreted coffee bean in Luwak feces
}

\author{
TOTO ISWANTO ${ }^{1,3}$, MAYA SHOVITRI $^{2}$, ALI ALTWAY ${ }^{3}$, TRI WIDJAJA ${ }^{1, \bullet}$, \\ DINIHARI INDAH KUSUMAWATI ${ }^{4}$, PUSPITA LISDIYANTI ${ }^{4}$ \\ ${ }^{1}$ Biochemical Technology Laboratory, Department of Chemical Engineering, Faculty of Industrial Technology, Institut Teknologi Sepuluh Nopember. Jl. \\ Raya ITS, Sukolilo, Surabaya 60111, East Java, Indonesia. Tel. +62-31-5946240, •email: triw @ chem-eng.its.ac.id \\ ${ }^{2}$ Microbiology and Biotechnology Laboratory, Department of Biology, Faculty of Science, Institut Teknologi Sepuluh Nopember. Jl. Raya ITS, Sukolilo, \\ Surabaya 60111, East Java, Indonesia \\ ${ }^{3}$ Heat and Mass Transport Laboratory, Department of Chemical Engineering, Faculty of Industrial Technology, Institut Teknologi Sepuluh Nopember, \\ Jl. Raya ITS, Sukolilo, Surabaya 60111, East Java, Indonesia \\ ${ }^{4}$ Research Center for Biotechnology, Indonesian Institute of Sciences. Jl. Raya Bogor Km 46, Cibinong, Bogor 16911, West Java, Indonesia
}

Manuscript received: 14 February 2019. Revision accepted: 13 May 2019

\begin{abstract}
Iswanto T, Shovitri M, Altway A, Widjaja T, Kusumawati DI, Lisdiyanti P. 2019. Isolation and identification of caffeinedegrading bacteria from soil, coffee pulp waste and excreted coffee bean in Luwak feces. Biodiversitas 20: 1580-1587. The present study deals with the isolation and identification of caffeine-degrading bacteria obtained from the caffeine contaminated environment or caffeinated wastes. These bacteria are useful for various biotechnological applications especially in increasing the potential utilization of caffeinated wastes and producing the high-value chemicals. The suspected caffeine-degrading bacteria have been isolated from the soil of coffee plantation area, coffee pulp waste, and the excreted coffee bean in fresh feces of Luwak (Paradoxurus hermaphroditus or Asian Palm Civet) by growing them on the caffeinated agar medium (CAM) containing basal salt medium (M9) and caffeine as a sole source of carbon and nitrogen. CAM-supplemented with 1.5 to $10 \mathrm{~g} \mathrm{~L}^{-1}$ of caffeine has been used for screening of the potential bacteria which able to grow in high caffeine concentration. Molecular identification based on 16S rRNA gene sequence was performed to identify the selected bacteria. The result revealed that there were 11 and 3 strains of 12 selected bacteria which could grow on the CAMsupplemented with caffeine up to 7 and $10 \mathrm{~g} \mathrm{~L}^{-1}$, respectively. Based on 16S rRNA gene sequence and phylogenetic analysis, those bacteria were from 5 Gram-negative species, namely Pseudomonas japonica (4/12), Methylobacterium populi (5/12), Raoultella ornithinolytica (1/12), Klebsiella quasipneumoniae (1/12), and Stenotrophomonas chelatiphaga (1/12). Further investigations to determine their metabolic pathway, enzyme, and growth kinetics in the caffeinated medium may provide insights into its possible utilization for scientific or other applications.
\end{abstract}

Keywords: 16S rRNA gene sequence, bacteria, caffeine, isolation, identification, phylogenetic analysis

\section{INTRODUCTION}

Indonesia is the top fourth largest coffee-producing country in the world after Brazil, Vietnam, and Colombia (Szenthe 2018). However, the presence of caffeine in its residual products such as coffee leaves, pulp, and husk have become the main limiting factor in its utilization, because of its role as anti-nutritional factor and inhibitor of microbial growth during the biological processes (Raj and Dhala 1965; Gokulakrishnan et al. 2005). Caffeine was regarded as toxic to microorganisms until early 1970 when Kurtzman Jr. and Schwimmer (1971) found that there were specific bacteria and fungi which were able to grow in the caffeinated medium. Since that, a number of developments have been carried out on utilizing caffeine as a sole source of carbon and nitrogen for isolation of new strain of caffeine-degrading bacteria or fungi.

In the last few years, the use of caffeine-degrading bacteria is a great demand as it is more advantageous than physical and chemical treatments which require special materials and expensive equipment (Gokulakrishnan and Gummadi 2006). That bacteria can be utilized for several biotechnological applications such as environmental remediation by reducing the caffeine level which is released into soil and water from the caffeinated wastes such as coffee pulp and husks and increase the biotechnological potential of these carbohydrate- and protein-rich wastes for animal feed, mushroom cultivation, and production of biogas, ethanol, enzymes and organic acids (Pandey et al. 2000; Dash and Gummadi 2006a). Moreover, some bacterial strains can produce high-value chemicals which resulted as metabolite products of caffeine degradation for pharmaceutical preparations, cosmetic, and human and animal nutrition such as methylxanthine, uric acid, methyluric acids, and 8-oxomethylxanthines (Mohanty 2013; Summers et al. 2015).

Due to those advantages, various efforts to find new bacterial strains have been conducted. Caffeine-degrading bacteria can be isolated from the caffeine contaminated environment or caffeinated waste (from tea and coffee) which was easily obtained in Indonesia. However, the reports of this study in Indonesia are still rarely found. To the best of our knowledge, there is only one report which successfully isolated and identified 14 caffeine-degrading bacteria from coffee pulp waste in Malangsari and Jampit coffee plantation, Indonesia. One of the bacteria was 
Pseudomonas monteilii KRM9 which was reported to have the highest caffeine degradation activity (Arimurti et al. 2017). Since Indonesia is a country with high biodiversity in the world (Butler 2016), its bacterial diversity was still interesting to be explored. Therefore, the aims of this study were to isolate and identify the potential bacteria from the various sources in Indonesia such as coffee pulp waste, soil from coffee plantation area, and excreted coffee bean in fresh feces of Asian Palm Civet which can grow in growth medium supplemented with high caffeine concentration. The identities of isolated bacteria were established via analysis of the $16 \mathrm{~S}$ rRNA gene sequence and phylogeny.

\section{MATERIALS AND METHODS}

\section{Bacterial isolation and purification}

Samples of coffee pulp wastes, soil from the coffee plantation area, and excreted coffee bean in fresh feces of Luwak (Paradoxurus hermaphroditus or Asian Palm Civet) were collected from Situbondo, Dampit, and Kediri in East Java, Indonesia.

The isolation of caffeine-degrading bacteria was conducted using methods described by Babu et al. (2005) using an enriched-caffeine liquid medium (CLM). It was prepared by dissolving basal salt medium (M9) which consisted of $6.4 \mathrm{~g}$ of $\mathrm{Na}_{2} \mathrm{HPO}_{4} 7 \mathrm{H}_{2} \mathrm{O}, 1.5 \mathrm{~g}$ of $\mathrm{KH}_{2} \mathrm{PO}_{4}$, $0.25 \mathrm{~g}$ of $\mathrm{NaCl}$, and $0.5 \mathrm{~g}$ of $\mathrm{NH}_{4} \mathrm{Cl}$ into $1 \mathrm{~L}$ of distilled water (Sambrook et al. 1989) and supplemented with $0.3 \mathrm{~g}$ of caffeine as a sole source of carbon and nitrogen. The $\mathrm{pH}$ of CLM was adjusted to 7.2 using $0.5 \mathrm{~N} \mathrm{NaOH}$.

For enrichment culture, $1 \mathrm{~g}$ of each sample was introduced into a $250 \mathrm{~mL}$ Erlenmeyer flask containing 100 $\mathrm{mL}$ of CLM. All cultures were incubated in a benchtop incubator shaker at $32^{\circ} \mathrm{C}$ and $120 \mathrm{rpm}$ for $72 \mathrm{~h}$. One $\mathrm{mL}$ of liquid from each culture was serially diluted using sterile distilled water from $10^{-1}$ to $10^{-7}$ folds. Then, $0.1 \mathrm{~mL}$ of an aliquot of $10^{-5}$ to $10^{-7}$ was spread on caffeinated agar medium (CAM) with $0.3 \mathrm{~g} \mathrm{~L}^{-1}$ of caffeine and incubated at $32^{\circ} \mathrm{C}$ for $72 \mathrm{~h}$. A single colony which has distinct shape and color grown on CAM were further purified on the fresh CAM until a pure culture was obtained. In these steps, CAM was made by addition of $18 \%$ of pure agar to CLM as same as the enrichment medium and poured it into the sterile petri dishes.

\section{Screening of the potential isolates}

The screening was performed by streaking the pure cultures on CAM with higher caffeine concentration stepwise from $1.5,3,5,7$, and $10 \mathrm{~g} \mathrm{~L}^{-1}$ to figure out their growing ability on the higher caffeine concentration.

In brief, every single colony was transferred to the fresh CAM containing $1.5 \mathrm{~g} \mathrm{~L}^{-1}$ of caffeine and incubated at $32^{\circ} \mathrm{C}$ for 7 days. The growing bacterial colony was then transferred again into fresh CAM with $3 \mathrm{~g} \mathrm{~L}^{-1}$ of caffeine concentration and incubated again at the same condition. These steps were repeated until caffeine concentration in CAM was $10 \mathrm{~g} \mathrm{~L}^{-1}$. The isolates capable of growing on
CAM with high caffeine concentration were selected for molecular identification analysis.

\section{Molecular identification of the potential isolates}

Identification of selected isolates was conducted using colony PCR based on 16S rRNA gene. An overnight single colony of each isolate grown on nutrient agar for a day was picked up into a sterile PCR tube and heated in a microwave for 2 minutes. This process could extract DNA from the cell. The $15 \mu \mathrm{L}$ of sterile nuclease-free water was put in that tube and vortexed for a moment until a homogeneous mixture, called DNA template. Its quality and quantity were examined by BioSpec-nano microvolume UV-Vis spectrophotometer (Shimadzu).

For the DNA amplification, the PCR reagent was prepared following the recommendation of GoTaq ${ }^{\circledR}$ Green Master Mix protocol (Promega Corporation, USA) with universal eubacterial primers 27F (5'-AGAGTTTGATCC TGGCTCAG-3') and 1492R (5'-GGTTACCTTGTTAC GACTT-3'). The PCR reagent was incubated in a PCR machine to generate amplicons of approximately 1500 base pairs (bp) in size, as the listed conditions in Table 1.

After the PCR amplification, the amplicons were confirmed using $1 \%$ agarose gel electrophoresis in TEA buffer pH 8.0 (40 mM Tris-Acetate, 1 mM EDTA) solution at 100 Volt for $20 \mathrm{~min}$ and stained with ethidium bromide solution and observed under UV transilluminator. Further, the qualified amplicons were sequenced at the $1^{\text {st }}$ BASE Laboratories in Malaysia.

The obtained 16S rRNA gene sequences have been analyzed using BioEdit program (Hall 1999) and initially identified using EzBioCloud's Identify service in EzBioCloud website: https://www.ezbiocloud.net (Yoon et al. 2017) to determine their similarity with validly published taxa name and type strains. All identified isolates and their 16S rRNA gene sequences were deposited in Indonesian Culture Collection (InaCC) and the GenBank of National Center for Biotechnology Information (NCBI), respectively. Their designation code/strain name in InaCC and accession numbers were recorded in Table 3.

\section{Phylogenetic analysis}

Multiple alignments of all 16S rRNA gene sequences were performed using ClustalW included in the software of Molecular Evolutionary Genetics Analysis version X (MEGA-X) (Kumar et al. 2018). All valid reference sequence with the accession number of bacterial type strains were obtained from EzBioCloud, list of prokaryotic names with standing in nomenclature (LPSN), and NCBI website. The unrooted phylogenetic tree was constructed by MEGA-X using a neighbor-joining statistical method (Saitou and Nei 1987) and the Kimura 2-parameter model (Kimura 1980) to quantify sequence similarity among the strains. The complete deletion was chosen for gaps in data treatment. Aquifex pyrophilus strain $\mathrm{KOL}^{\mathrm{T}} \mathrm{A}^{\mathrm{T}}$ and Hydrogenivirga okinawensis strain $\mathrm{LS} 12-2^{\mathrm{T}}$ were used as out-group in constructing the phylogenetic tree. 
Table 1. Operating conditions of the PCR amplification

\begin{tabular}{lcl}
\hline \multicolumn{1}{c}{ Treatment } & Temperature & Time \\
\hline Pre denaturation & $96^{\circ} \mathrm{C}$ & $5 \mathrm{~min}$ \\
Subsequently followed by 35 cycles of; & & \\
Denaturation & $96^{\circ} \mathrm{C}$ & $30 \mathrm{~s}$ \\
Annealing & $55^{\circ} \mathrm{C}$ & $30 \mathrm{~s}$ \\
Elongation & $72^{\circ} \mathrm{C}$ & $1 \mathrm{~min}$ \\
Extention & $72^{\circ} \mathrm{C}$ & $7 \mathrm{~min}$ \\
Stand-by & $4^{\circ} \mathrm{C}$ & $\infty$ \\
\hline
\end{tabular}

\section{RESULTS AND DISCUSSION}

Caffeine-degrading bacteria can be isolated using a specific medium containing caffeine as a sole source of carbon and nitrogen. As the preliminary investigation, it can become an easy way before subjecting to the advanced identification of its enzyme or metabolites. Some studies have used caffeine in the range of $0.1-2.5 \mathrm{~g} \mathrm{~L}^{-1}$ as the initial concentration (Mazzafera et al. 1996; Babu et al. 2005; Gokulakrishnan and Gummadi 2006; Yu et al. 2008, 2009). The presence of $0.1 \%$ caffeine in the growth medium has been reported to inhibit protein synthesis (Ibrahim et al. 2014)' while concentration above $2.5 \mathrm{mg} \mathrm{mL}^{-1}$ could inhibit the growth of many bacterial species (Gokulakrishnan et al. 2005). In addition, caffeine could induce mutagenic effects which inhibit ultraviolet wound repair and DNA synthesis in Escherichia coli (Sandlie et al. 1980). In this study, we conducted isolation, screening, and identification of selected strains to utilize caffeine from 1.5 to $10 \% \mathrm{~g} \mathrm{~L}^{-1}$.
Isolation and screening of caffeine-degrading bacteria

In this study, the bacterial colonies were isolated aerobically and tested to grow on CAM in the several concentrations of caffeine. In the initial process of isolation using CAM-supplemented with $0.3 \mathrm{~g} \mathrm{~L}^{-1}$ of caffeine, 62 colonies of bacteria were selected; 16 from each coffee pulp waste in Situbondo and Dampit, 5 from the soil of coffee plantation area in Situbondo, and 11, 5, and 9 from coffee bean in feces of Luwak which were obtained from Situbondo, Dampit, and Kediri, respectively. In the screening process, all selected isolates could grow on CAM-supplemented with $1.5 \mathrm{~g} \mathrm{~L}^{-1}$ of caffeine after 2-4 days incubation. However, only 12 isolates could grow on CAM contained 3 and $5 \mathrm{~g} \mathrm{~L}^{-1}$ of caffeine and less of which for caffeine concentration of 7 to $10 \mathrm{~g} \mathrm{~L}^{-1}$ after 3-7 days incubation, as shown in Figure 1 and Table 2.

Figure 1 shows the morphological appearance of the isolates. Using the naked eye, general shape and chromogenesis of isolates were determined. Isolates C9, C49, C52, and C57 have small colonies, creamy white to pale yellow, circular, flat, opaque and slightly spreading edge. Other characteristics; small colonies, pink pigment, opaque, convex, and round was observed in C20, C22, $\mathrm{C} 25, \mathrm{C} 29$, and C39. Isolate C28 has large and small colonies with a slightly undulate edge, white pale, and umbonate elevation. C32 has small colonies, pale yellow, flat, and opaque. On the other hand, C56A has small colonies with slightly irregular shape, white pale, and raised elevation. These isolates were chosen for the molecular identification analysis.
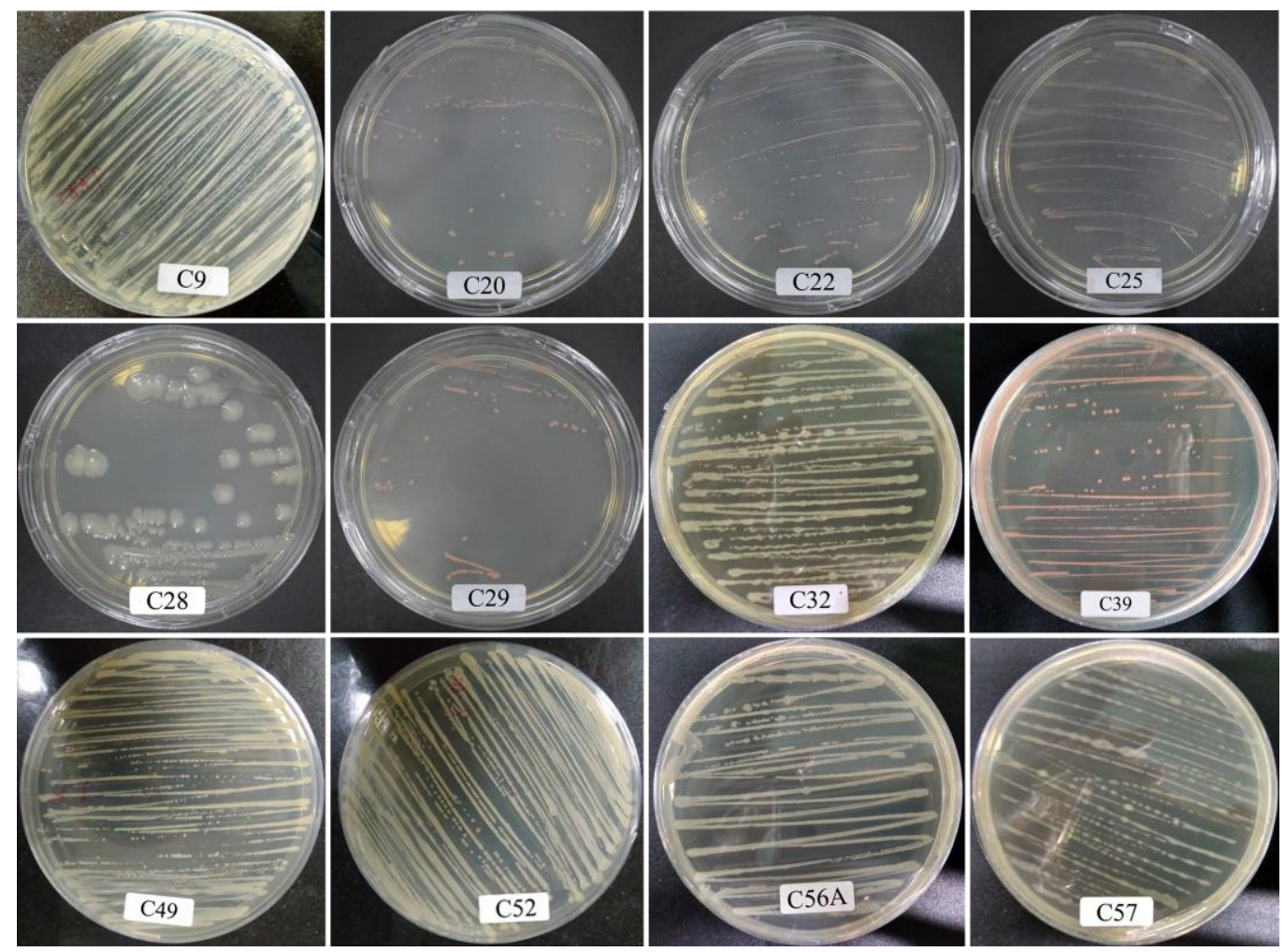

Figure 1. Twelve bacterial isolates which were able to grow on the caffeinated agar medium 
Table 2. Isolated bacteria from the various sources in East Java, Indonesia

\begin{tabular}{|c|c|c|c|c|c|c|}
\hline \multirow{2}{*}{ Sample } & \multirow{2}{*}{ Designation } & \multicolumn{5}{|c|}{ Ability to grow on CAM with initial caffeine concentration of } \\
\hline & & $1.5\left(\mathrm{~g} \mathrm{~L}^{-1}\right)$ & $3\left(\mathrm{~g} \mathrm{~L}^{-1}\right)$ & $5\left(g^{-1}\right)$ & $7\left(\mathrm{~g} \mathrm{~L}^{-1}\right)$ & $10\left(\mathrm{~g} \mathrm{~L}^{-1}\right)$ \\
\hline Coffee pulp waste $^{1}$ & C39 & + & + & + & + & - \\
\hline Coffee pulp waste ${ }^{2}$ & C9 & + & + & + & + & - \\
\hline Soil from coffee plantation area ${ }^{1}$ & $\mathrm{C} 20$ & + & + & + & + & - \\
\hline \multirow[t]{5}{*}{ Coffee bean in feces of $L_{u w a k}{ }^{1}$} & $\mathrm{C} 22$ & + & + & + & + & - \\
\hline & $\mathrm{C} 25$ & + & + & + & + & - \\
\hline & $\mathrm{C} 28$ & + & + & + & + & + \\
\hline & $\mathrm{C} 29$ & + & + & + & + & - \\
\hline & $\mathrm{C} 32$ & + & + & + & - & - \\
\hline \multirow[t]{2}{*}{ Coffee bean in feces of $L u w a k^{2}$} & $\mathrm{C} 49$ & + & + & + & + & - \\
\hline & C52 & + & + & + & + & - \\
\hline \multirow[t]{2}{*}{ Coffee bean in feces of $L u w a k^{3}$} & C56A & + & + & + & + & + \\
\hline & C57 & + & + & + & + & + \\
\hline
\end{tabular}

Note: ${ }^{1}$ : obtained from Situbondo; ${ }^{2}$ : obtained from Dampit; ${ }^{3}$ : obtained from Kediri; “+”: growing; "-": not growing

The data in Table 2 indicates that the isolates have different ability to grow on CAM with various concentrations of caffeine. They have shown good potential due to their ability to tolerate caffeine which requires further investigation regarding their optimal growth condition and caffeine-degrading efficiency. In other studies, Pseudomonas sp. GSC 1182 had been tested to grow on various concentrations of caffeine ranging from 0.05 to $20 \mathrm{~g} \mathrm{~L}^{-1}$. The result showed that its maximum growth rate was obtained in medium containing $2.5 \mathrm{~g} \mathrm{~L}^{-1}$ of initial caffeine concentration. That strain was able to completely consume caffeine within $48 \mathrm{~h}$ when the initial concentration was up to $4 \mathrm{~g} \mathrm{~L}^{-1}$ and only $50 \%$ of caffeine in $72 \mathrm{~h}$ when the initial substrate concentration was $5-10 \mathrm{~g} \mathrm{~L}^{-1}$ (Gokulakrishnan and Gummadi 2006). Yu et al. (2015) also reported that Pseudomonas sp. CES can degrade caffeine with the concentration of $9.0 \mathrm{~g} \mathrm{~L} \mathrm{~L}^{-1}$. Another one, Pseudomonas sp. NCIM 5235, isolated from the soil of coffee plantation area, was reported to degrade high concentration of caffeine $\left(6.4 \mathrm{~g} \mathrm{~L}^{-1}\right)$ in $24 \mathrm{~h}$ (Dash and Gummadi 2007). It was maintained on caffeine associated sucrose (CAS) agar medium and subcultured once a week to prevent the loss of its caffeine-degrading ability. Under optimal growth condition in the bioreactor, this strain was found to degrade $100 \%$ caffeine with initial caffeine concentration of $20 \mathrm{~g} \mathrm{~L}^{-1}$ (Gummadi and Santhosh 2010). This was the best strain withstanding higher concentrations of caffeine reported so far.

\section{Molecular identification based on 16S rRNA gene}

Amplification process using the primers 27F and 1492R was aimed to get the complete $16 \mathrm{~S}$ rRNA gene, the size around 1400-1500 bp, for yielding high similarity with the valid taxa name in the GenBank.

The size of all amplicons was analyzed and resulted in approximately $1,500 \mathrm{bp}$ in the agarose gel, as shown in Figure 2. The exact number of base pairs would be confirmed after nucleotide sequencing. On the upstream and downstream region of sequence, several nucleotides was deleted due to the presence of an irregular peak in the chromatogram. Their final size was used for checking identification via EzBioCloud's Identify service (Table 3).
The identification result revealed that some isolates were from the genus of Klebsiella, Methylobacterium, Pseudomonas, Raoultella, and Stenotrophomonas. All listed taxa in Table 4 are reported as Gram-negative and aerobic bacteria except $K$. quasipneumoniae and $R$. ornithinolytica which are a facultative anaerobe. The evolutionary mapping of isolates is shown in phylogenetic trees in Figure 3.

The phylogenetic tree based on the 16S rRNA gene sequences shows that strains C9, C49, C52, and C57 have an apparent relationship with bacteria belonging to the Pseudomonas assemblage and formed a stable phylogenetic position, close to the strain $P$. japonica NBRC $103040^{\mathrm{T}}$ (BBIR01000146) with $76 \%$ bootstrap value and $>98 \%$ similarity (Figure 3a and Table 3). Those 4 strains formed new cluster in the genus Pseudomonas. The position of strains C20, C22, C25, C29, and C39 showed close to Methylobacterium populi type strain ${\mathrm{BJ} 001^{\mathrm{T}}}$ (CP001029) with $99 \%$ bootstrap value, which was isolated from internal poplar tissues and able to utilize methane as carbon and energy (Aken et al. 2004). The sequence similarity of strain C32 was $98.25 \%$ close to strain belonging to species $S$. chelatiphaga DSM 21508 ${ }^{\mathrm{T}}$ (LDJK01000058), isolated from municipal sewage sludge and reported equivalent with $S$. chelatiphaga sp. nov. type strain LPM- $5^{\mathrm{T}}=\mathrm{VKM}$ B-2486 = CCUG 57178 (Kaparullina et al. 2009).

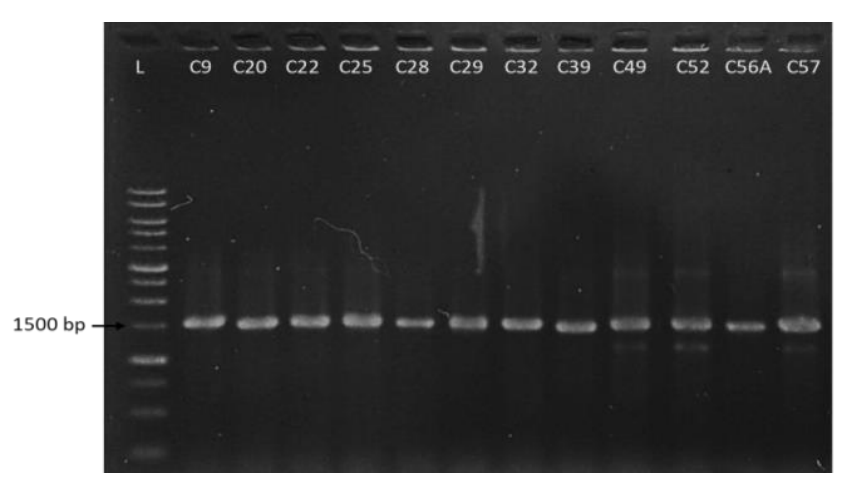

Figure 2. PCR products electrophoresed of the isolates on $1 \%$ agarose gel. The molecular size was approximately $1,500 \mathrm{bp}$. $\mathrm{L}$ is the DNA ladder with $1 \mathrm{~kb}$ DNA marker 
Table 3. Results for the identification of isolates based on 16S rRNA gene sequence

\begin{tabular}{|c|c|c|c|c|c|}
\hline $\begin{array}{c}\text { Designation } \\
\text { (strain code in InaCC) }\end{array}$ & $\begin{array}{c}\text { Accession } \\
\text { number }\end{array}$ & $\begin{array}{c}\text { Top-hit taxon } \\
\text { (Accession number) }\end{array}$ & Top-hit strain & $\begin{array}{c}\text { Sequence } \\
\text { similarity } \\
(\%)\end{array}$ & $\begin{array}{l}\text { Sequence } \\
\text { size (bp) }\end{array}$ \\
\hline C9 (InaCC B1340) & MK336722 & Pseudomonas japonica (BBIR01000146) & NBRC $103040^{\mathrm{T}}$ & 98.89 & 1423 \\
\hline C20 (InaCC B1341) & MK336723 & Methylobacterium populi (CP001029) & $\mathrm{BJ} 001^{\mathrm{T}}$ & 99.78 & 1368 \\
\hline C22 (InaCC B1342) & MK336724 & Methylobacterium populi (CP001029) & BJ001 & 99.85 & 1367 \\
\hline C25 (InaCC B1343) & MK336725 & Methylobacterium populi (CP001029) & $\mathrm{BJ} 001^{\mathrm{T}}$ & 99.85 & 1367 \\
\hline C28 (InaCC B1344) & MK336726 & Raoultella ornithinolytica (AJ251467) & JCM $6096^{\mathrm{T}}$ & 98.38 & 1422 \\
\hline C29 (InaCC B1345) & MK336727 & Methylobacterium populi (CР001029) & $\mathrm{BJ} 001^{\mathrm{T}}$ & 99.90 & 1020 \\
\hline C32 (InaCC B1346) & MK336728 & Stenotrophomonas chelatiphaga (LDJK01000058) & DSM $21508^{\mathrm{T}}$ & 98.25 & 1430 \\
\hline C39 (InaCC B1347) & MK336729 & Methylobacterium populi (CP001029) & $\mathrm{BJ}_{001^{\mathrm{T}}}^{\mathrm{T}}$ & 99.63 & 1355 \\
\hline C49 (InaCC B1348) & MK336730 & Pseudomonas japonica (BBIR01000146) & NBRC $103040^{\mathrm{T}}$ & 98.00 & 1417 \\
\hline C52 (InaCC B1350) & MK336732 & Pseudomonas japonica (BBIR01000146) & NBRC $103040^{\mathrm{T}}$ & 98.59 & 1419 \\
\hline C56A (InaCC B1359) & MK336733 & Klebsiella quasipneumoniae (HG933296) & $01 \mathrm{~A} 030^{\mathrm{T}}$ & 99.86 & 1418 \\
\hline C57 (InaCC B1351) & MK336734 & Pseudomonas japonica (BBIR01000146) & NBRC $103040^{\mathrm{T}}$ & 98.80 & 1416 \\
\hline
\end{tabular}

Table 4. The current reported caffeine-degrading bacteria

\begin{tabular}{|c|c|c|c|}
\hline Name of isolate & Source of isolate & Region & Reference \\
\hline Bacillus coagulans & Soil & Not reported & Kurtzman Jr. and Schwimmer (1971) \\
\hline P. putida strain 40 & Soil & California & Woolfolk (1975) \\
\hline P. putida $\mathrm{C} 1$ & Soil & Germany & Blecher and Lingens (1977) \\
\hline P. putida $\mathrm{C} 3024$ & Garden soil & Netherlands & Middelhoven and Bakker (1982) \\
\hline P. putida WS & Soil & Germany & Glück and Lingens (1987) \\
\hline Pseudomonas. sp. No. 6 & Soil & Japan & Asano et al. (1993) \\
\hline P. putida No. 352 & Soil & Japan & Asano et al. (1993) \\
\hline Serratia marcescens & Soil under coffee tree & Brazil & Mazzafera et al. (1996) \\
\hline P. putida ATCC 700097 & Wastewater streams & California & Ogunseitan (1996) \\
\hline Klebsiella and Rhodococcus & Soil & India & Madyastha and Sridhar (1998) \\
\hline P. putida (8 strains) & Soil under coffee tree & Brazil & Yamaoka-Yano and Mazzafera (1998) \\
\hline P. fluorescens & Soil under coffee tree & Brazil & Yamaoka-Yano and Mazzafera (1998) \\
\hline Coryneform (4 strains) & Soil under coffee tree & Brazil & Yamaoka-Yano and Mazzafera (1998) \\
\hline Acinetobacter sp. (3 strains) & Soil under coffee tree & Brazil & Yamaoka-Yano and Mazzafera (1998) \\
\hline Flavobacterium sp. (2 strains) & Soil under coffee tree & Brazil & Yamaoka-Yano and Mazzafera (1998) \\
\hline Moraxella sp. & Soil under coffee tree & Brazil & Yamaoka-Yano and Mazzafera (1998) \\
\hline P. putida IF-3 and its mutants & Soil & Japan & Yoshinao et al. (1996) \\
\hline P. putida $\mathrm{L}$ & Soil under coffee tree & Brazil & Yamaoka-Yano and Mazzafera (1999) \\
\hline P. putida KD6 & Not reported & Not reported & Sideso et al. (2001) \\
\hline P. alcaligenes CFR 1708 & Soil of coffee plantation & India & Babu et al. (2005) \\
\hline Alcaligenes fecalis $\mathrm{T} 1$ & Not reported & India & Babu et al. (2005) \\
\hline Acetobacter sp. T3 & Not reported & India & Babu et al. (2005) \\
\hline Alcaligenes sp.CF8 & Surface water of lake & Canada & Mohapatra et al. (2006) \\
\hline P. putida NCIM 5235 & Soil of coffee plantation & India & Dash and Gummadi (2006b) \\
\hline Pseudomonas sp. GSC 1182 & Soil of coffee plantation & India & Gokulakrishnan and Gummadi (2006) \\
\hline Pseudomonas sp. CBB1 & Soil & Iowa & Yu et al. (2008) \\
\hline P. putida CBB5 & Soil & Iowa & Yu et al. (2009) \\
\hline P. stutzeri $\mathrm{Gr} 21 \mathrm{ZF}$ & Soil & Lebanon & Zakia et al. (2013) \\
\hline P. pseudoalcaligenes TPS8 & Soil of tea plantation & Iran & Ashengroph and Ababaf (2013) \\
\hline Pseudomonas sp. CES & Coffee waste & Iowa & Yu et al. (2015) \\
\hline P. monteilii KRM9 & Coffee pulp waste & Indonesia & Arimurti et al. (2017) \\
\hline P. putida $\mathrm{CT} 25$ & Soil of tea garden & China & Ma et al. (2018) \\
\hline P. japonica $\mathrm{C} 9$ & Coffee pulp waste & Indonesia & In this study \\
\hline P. japonica (3 strains) & Coffee bean in Luwak feces & Indonesia & In this study \\
\hline M. populi C39 & Coffee pulp waste & Indonesia & In this study \\
\hline M. populi $\mathrm{C} 20$ & Soil of coffee plantation & Indonesia & In this study \\
\hline M. populi (3 strains) & Coffee bean in Luwak feces & Indonesia & In this study \\
\hline K. quasipneumoniae & Coffee bean in Luwak feces & Indonesia & In this study \\
\hline$R$. ornithinolytica $\mathrm{C} 28$ & Coffee bean in Luwak feces & Indonesia & In this study \\
\hline S. chelatiphaga $\mathrm{C} 32$ & Coffee bean in Luwak feces & Indonesia & In this study \\
\hline
\end{tabular}




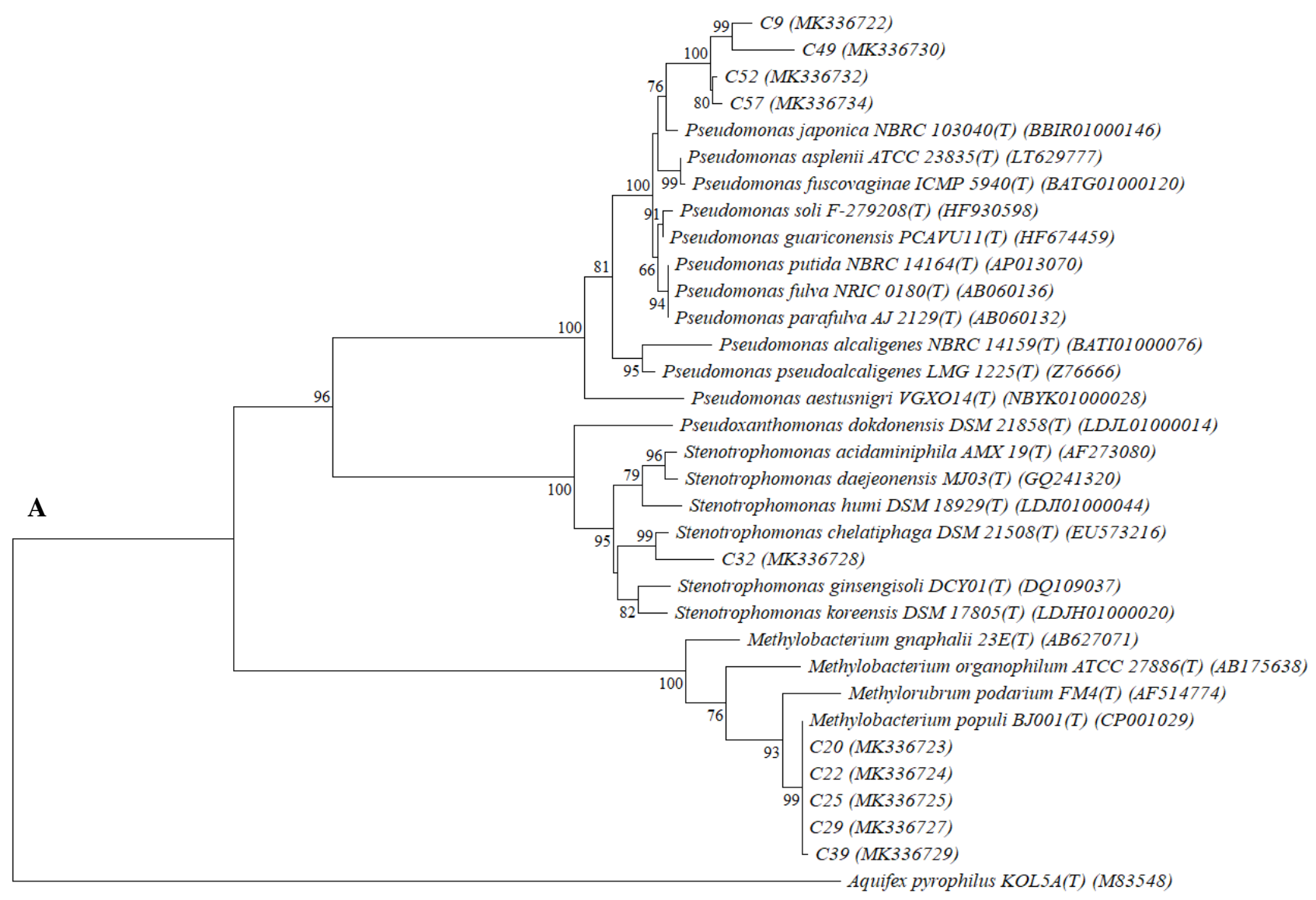

0.050

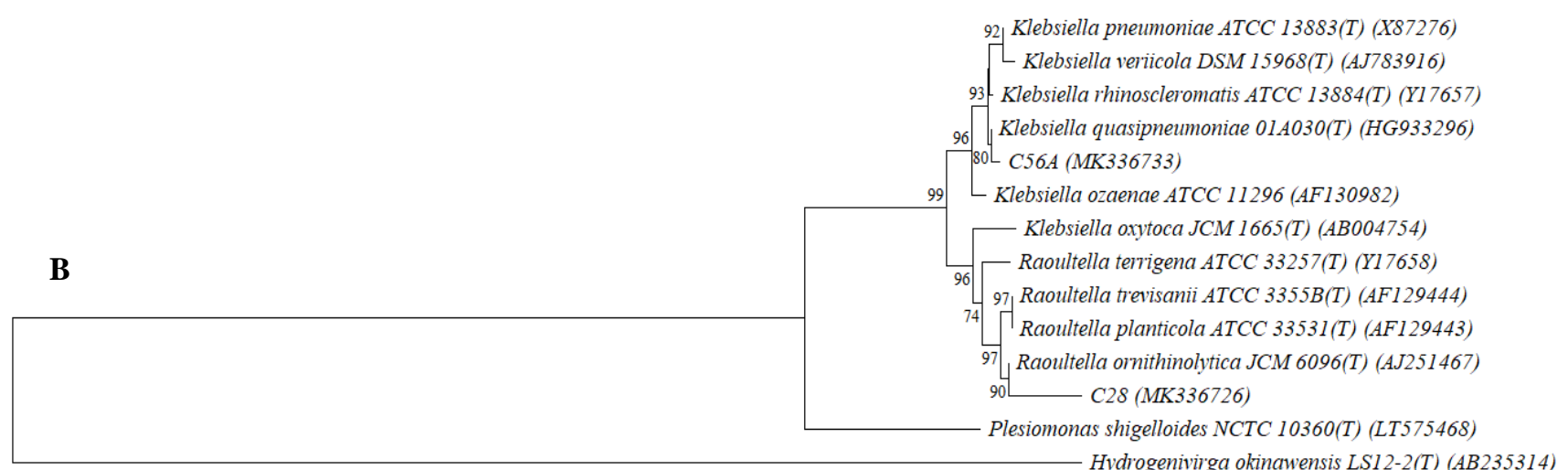

0.050

Figure 3. The phylogenetic tree based on the partial sequence of the 16S rRNA gene was constructed using the Neighbor-Joining method in MEGA-X with 1000 of bootstrap replicates that shows the evolutionary relationship between isolates and other species from GeneBank. The bootstrap value is shown at the branch indicates levels of confidence. Bootstrap values lower than $60 \%$ are not shown. The scale shows substitution on each nucleotide. (T): type of strain. The accession number for the 16S rRNA gene sequence is written after the strain name in parenthesis.

The strains C28 and C56A were identified from the cluster belonging to Klebsiella and obtained in the samples of coffee bean in Luwak feces from Situbondo and Kediri, respectively. This was not surprising because the previous study of Madyastha et al. (1999) has also found that a mixed culture of Klebsiella and Rhodococcus could utilize 
and convert caffeine to 1,3,7-trimethyl uric acid. In the phylogenetic tree (see Figure 3b), strain C28 was placed in the cluster of Raoultella with $90 \%$ bootstrap value and $98.38 \%$ similarity, close to the type stain $R$. ornithinolytica JCM 6096 ${ }^{\mathrm{T}}$ (AJ251467) which has a basonym as Klebsiella ornithinolytica (Drancourt et al. 2001). The previous study has reported that $K$. ornithinolytica was confirmed from the same cluster with $K$. planticola due to the high sequence similarity which has a species-specific nucleotides within a 165-bp stretch of their 16S rDNA sequences (Boye and Hansen 2003). The sequence similarity and bootstrap of strain 56 A were $99.86 \%$ and $80 \%$, respectively, close to $K$. quasipneumoniae 01A030(T) (HG933296), isolated from human blood cultures by Brisse et al. (2014).

Some bacteria and fungi were reported capable of utilizing caffeine as a source of carbon and nitrogen. However, bio-decaffeination using bacteria was more commercially applicable due to its rapid growth without requiring a wide scope of space. Moreover, bacteria are able to grow at extreme temperature and $\mathrm{pH}$ and easy to genetically manipulate than fungi (Dash and Gummadi 2006a). Among the reported strains of caffeine-degrading bacteria, a few of which are Pseudomonas sp. that were isolated from the different environment and region, as shown in Table 4.

Caffeine catabolism by bacteria occurs through two pathways namely $\mathrm{N}$-demethylation with the help of $\mathrm{N}$ demethylase enzyme and C8 oxidation with caffeine oxidase and xanthine oxidase enzymes (Summers et al. 2015). In this study, caffeine catabolism by the isolates was not explored. Further investigation was needed to utilize these isolated bacteria which could be applied for producing the decaffeinated coffee bean in vitro, in cooperation with xylanolytic, cellulolytic, and proteolytic bacteria that have been isolated from Luwak feces by other researchers (Fauzi 2008; Dewi et al. 2015). This can prevent the exploitation of Luwak for in vivo coffee bean fermentation through its the gastrointestinal tract.

In conclusion, bacteria that can grow in enriched caffeine medium have been isolated and identified from the soil, coffee pulp waste, and excreted coffee bean in feces of Luwak (Asian palm civet). Each isolate showed different ability to grow in a growth medium containing various caffeine concentrations ranging from 1.5 to $10 \mathrm{~g} \mathrm{~L}^{-1}$. The potential isolates have been identified as species belonging to the genera Klebsiella, Methylobacterium, Pseudomonas, Raoultella, and Stenotrophomonas which were indicated by high similarity of 16s rRNA gene sequence and bootstrap value in phylogenetic analysis. All the isolates were deposited in InaCC. Next study regarding the catabolism pathway, optimum growth condition, and caffeinedegrading ability of each isolate are interesting topics for further application.

\section{ACKNOWLEDGMENTS}

The authors would like to acknowledge Ministry of Research, Technology and Higher Education of the Republic of Indonesia for the financial support by grant research of PMDSU scholarship [grant number 329/SP2H/ LT/DRPM/IX/2016, 2016]. We also thank all researchers, staff of InaCC and Research Center for Biotechnology, Indonesian Institute of Sciences (LIPI), and crews of Biochemical Technology Laboratory, especially for Rizal Aditama and Shada Zhafira, for their endless support and help.

\section{REFERENCES}

Aken BV, Peres CM, Doty SL, Yoon JM, Schnoor JL. 2004. Methylobacterium populi sp. nov., a novel aerobic, pink-pigmented, facultatively methylotrophic, methane-utilizing bacterium isolated from poplar trees (Populus deltoides x nigra DN34). Int J Syst Evol Microbiol 54: 1191-1196.

Arimurti S, Ardyati T, Nurabi Y, Siswoyo TA, Suharjono S. 2017. Degradation of caffeine by Pseudomonas monteilii KRM9. Malays J Microbiol 14: 55-60.

Asano Y, Komeda T, Yamada H. 1993. Microbial production of theobromine from caffeine. Biosci Biotechnol Biochem 57: 12861289.

Ashengroph M, Ababaf S. 2013. biodecaffeination by Pseudomonas pseudoalcaligenes TPS8, an isolated strain from tea plantation soil. J Sci Islam Repub Iran 24: 305-312.

Babu VRS, Patra S, Thakur MS, Karanth, NG, Varadaraj MC. 2005. Degradation of caffeine by Pseudomonas alcaligenes CFR 1708. Enzyme Microb Technol 37: 617-624.

Blecher R, Lingens F. 1977. The metabolism of caffeine by a Pseudomonas putida strain. Hoppe Seylers Z Physiol Chem 358: 807817.

Boye K, Hansen DS. 2003. Sequencing of 16S rDNA of Klebsiella: taxonomic relations within the genus and to other Enterobacteriaceae. Int J Med Microbiol 292: 495-503.

Brisse S, Passet V, Grimont PAD. 2014. Description of Klebsiella quasipneumoniae sp. nov., isolated from human infections, with two nov., and demonstration that Klebsiella singaporensis is a junior heterotypic synonym of Klebsiella variicola. Int $\mathbf{J}$ Syst Evol Microbiol 64: 3146-3152.

Butler RA, 2016. The top 10 most biodiverse countries, What are the world's most biodiverse countries? https://news.mongabay.com

Dash SS, Gummadi SN, 2006a. Catabolic pathways and biotechnological applications of microbial caffeine degradation. Biotechnol Lett 28: 1993-2002.

Dash SS, Gummadi SN. 2006b. Biodegradation of Caffeine by Pseudomonas sp. NCIM 5235. Res J Microbiol 1: 115-123.

Dash SS, Gummadi SN. 2007. Degradation kinetics of caffeine and related methylxanthines by induced cells of Pseudomonas sp. Curr Microbiol 55: 56-60.

Dewi SL, Meryandini A, Sunarti CT. 2015. Isolation of xylanolytic and cellulolytic bacteria from civet feces. Bogor Agricultural University, Bogor, [Indonesian].

Drancourt M, Bollet C, Carta A, Rousselier P. 2001. Phylogenetic analyses of Klebsiella species delineate Klebsiella and Raoultella gen. nov., with description of Raoultella ornithinolytica comb. nov., Raoultella terrigena comb. nov. and Raoultella planticola comb. nov. Int J Syst Evol Microbiol 51: 925-932.

Fauzi M. 2008. Isolasi dan karakterisasi bakteri asam laktat biji kopi luwak (Civet Coffe). Jember University, Jember, [Indonesian]

Glück M, Lingens F. 1987. Studies on the microbial production of theobromine and heteroxanthine from caffeine. Appl Microbiol Biotechnol 25: 334-340.

Gokulakrishnan S, Chandraraj K, Gummadi SN. 2005. Microbial and enzymatic methods for the removal of caffeine. Enzyme Microb Technol 37: 225-232.

Gokulakrishnan S, Gummadi SN. 2006. Kinetics of cell growth and caffeine utilization by Pseudomonas sp. GSC 1182. Process Biochem 41: 1417-1421.

Gummadi SN, Santhosh D. 2010. Kinetics of growth and caffeine demethylase production of Pseudomonas sp. in bioreactor. J Ind Microbiol Biotechnol 37: 901-908. 
Hall TA. 1999. BioEdit: a user-friendly biological sequence alignment editor and analysis program for Windows 95/98/NT. Nucleic Acids Symp Ser 41: 95-98

Ibrahim S, Shukor MY, Syed MA, Rahman NAA, Khalil KA, Khalid A, Ahmad SA. 2014. Bacterial degradation of caffeine: A review. Asian J Plant Biol 2: 18-27.

Kaparullina E, Doronina N, Chistyakova T, Trotsenko Y. 2009 Stenotrophomonas chelatiphaga sp. nov., a new aerobic EDTAdegrading bacterium. Syst Appl Microbiol 32: 157-162.

Kimura M. 1980. A simple method for estimating evolutionary rates of base substitutions through comparative studies of nucleotide sequences. J Mol Evol 16: 111-120.

Kumar S, Stecher G, Li M, Knyaz C, Tamura K. 2018. MEGA X molecular evolutionary genetics analysis across computing platforms. Mol Biol Evol 35: 1547-1549.

Kurtzman JRH, Schwimmer S. 1971. Caffeine removal from growth media by microorganisms. Experientia 27: 481-482.

Ma YX, Wu XH, Wu HS, Dong ZB, Ye JH, Zheng XQ, Liang YR, Lu J. 2018. Different catabolism pathways triggered by various methylxanthines in caffeine-tolerant bacterium Pseudomonas putida CT25 isolated from tea garden soil. J Microbiol Biotechnol 28 (7): $1147-1155$

Madyastha KM, Sridhar GR. 1998. A novel pathway for the metabolism of caffeine by a mixed culture consortium. Biochem Biophys Res Commun 249: 178-181.

Madyastha KM, Sridhar GR, Vadiraja BB, Madhavi YS. 1999. Purification and partial characterization of caffeine oxidase-A novel enzyme from a mixed culture consortium. Biochem Biophys Res Commun 263: 460-464.

Mazzafera P, Olsson O, Sandberg G. 1996. degradation of caffeine and related methylxanthines by Serratia marcescens isolated from soil under coffee cultivation. Microb Ecol 31: 199-207.

Middelhoven WJ, Bakker CM. 1982. Degradation of caffeine by immobilized cells of Pseudomonas putida strain C3024. Eur J App Microbiol Biotechnol 15: 214-217.

Mohanty SK. 2013. A genetic characterization of the caffeine C-8 oxidation pathway in Pseudomonas sp. CBB1 B. Validation of caffeine dehydrogenase as a suitable enzyme for a rapid caffeine diagnostic test. University of Iowa, Iowa, [United States].

Mohapatra BR, Harris N, Nordin R, Mazumder A. 2006. Purification and characterization of a novel caffeine oxidase from Alcaligenes species. J Biotechnol 125: 319-327.

Ogunseitan OA.1996. Removal of caffeine in sewage by Pseudomonas putida: implications for water pollution index. World $\mathrm{J}$ Microbiol Biotechnol 12: 251-256.

Pandey A, Soccol CR, Nigam P, Brand D. 2000. Biotechnological potential of coffee pulp and coffee husk for bioprocesses. Biochem Eng J 6: 153-162.
Raj CVS, Dhala S. 1965. Effect of naturally occurring xanthines on bacteria I. antimicrobial action and potentiating effect on antibiotic spectra. Appl Microbiol 13: 432-436.

Saitou N, Nei M. 1987. The neighbor-joining method: A new method for reconstructing phylogenetic trees. Mol Biol Evol 4: 406-425.

Sambrook J, Fritsch EF, Maniatis T. 1989. Molecular Cloning: a Laboratory Manual, 2nd ed. Cold Spring Harbor Laboratory Press, New York.

Sandlie I, Solberg K, Kleppe K. 1980. The effect of caffeine on cell growth and metabolism of thymidine in Escherichia coli. Mutat Res 73: $29-41$.

Sideso OFP, Marvier AC, Katerelos NA, Goodenough PW. 2001. The characteristics and stabilization of a caffeine demethylase enzyme complex. Intl J Food Sci Technol 36: 693-698.

Summers RM, Mohanty SK, Gopishetty S, Subramanian M. 2015. Genetic characterization of caffeine degradation by bacteria and its potential applications. Microb Technol 8 (3): 369-378.

Szenthe A. 2018. Top Coffee Producing Countries. https://www.worldatlas.com

Woolfolk CA. 1975. Metabolism of N-methylpurines by a Pseudomonas putida strain isolated by enrichment on caffeine as the sole source of carbon and nitrogen. J Bacteriol 123: 1088-1106.

Yamaoka-Yano DM, Mazzafera P. 1998. Degradation of caffeine by Pseudomonas putida isolated from soil under coffee cultivation. Allelopath J 5: 23-24.

Yamaoka-Yano, DM, Mazzafera, P. 1999. Catabolism of caffeine and purification of a xanthine oxidase responsible for methyluric acids production in Pseudomonas putida L. Rev Microbiol 30: 62-70.

Yoon SH, Ha SM, Kwon S, Lim J, Kim Y, Seo H, Chun J. 2017. Introducing EzBioCloud: A taxonomically united database of $16 \mathrm{~S}$ rRNA gene sequences and whole-genome assemblies. Int J Syst Evol Microbiol 67: 1613-1617.

Yoshinao K, Seiji N, Yutaka I. 1996. Caffeine demethylate genecontaining DNA fragment and microbial process for producing 3methyl-7-alkylxanthine.

Yu CL, Kale Y, Gopishetty S, Louie TM, Subramanian M. 2008. A novel caffeine dehydrogenase in Pseudomonas sp. strain CBB1 oxidizes caffeine to trimethyluric acid. J Bacteriol 190: 772-776.

Yu CL, Louie TM, Summers R, Kale Y, Gopishetty S, Subramanian M. 2009. Two distinct pathways for metabolism of theophylline and caffeine are coexpressed in Pseudomonas putida CBB5. J Bacteriol 191: 4624-4632.

Yu CL, Summers RM, Li Y, Mohanty SK, Subramanian M, Pope RM. 2015. Rapid identification and quantitative validation of a caffeinedegrading pathway in Pseudomonas sp. CES. J Proteome Res 14: 95106.

Zakia O, F E-Mched, Holaih H. 2013. Optimization of the environmental and physiological factors affecting microbial caffeine degradation and its application in caffeinated products. Basic Res J Mcrobiology 1: 17-27. 